Comarr, A. E. (1955). F. Urol. 74, 447.

DAMANSKi, M. (1967). Hosp. Med. 2, 39.

DAMANSKI, M. \& GibBon, N. O. K. (1956), Br. f. Urol. 28, 24.

David, V. C. (I92 I). F. Am. med. Ass. 76, 494.

Gibbon, N. O. K., Ross, J. C. \& Damanski, M. (1965). Int. F. Paraplegia, 2, 264.

GrifFith, H. L. (I956). Quoted by Ross, J. C., in Handbook Encyclopedia of Urology, Vol. I2, p. I03.

Guze, L. B. \& Beeson, P. B. (1956). New Engl. Med. F. 255, 474.

Guze, L. B. \& Kalmanson, G. M. (1964). Science, N.Y. 143, I340.

HAGER, B. N. (1926). F. Urol. 16, 447.

HANLEY, H. G. (1963). Lancet, I, 22.

Helmholz, H. F. Snr. (I950). F. Urol. 64, I 58.

Hutch, J. A. (1957). F. Urol. 77, I23.

HUTCH, J. A. \& BUNTS, R. C. (I95I). F. Urol. 66, 2 I8.

JAMESON, R. M. (1966). Br. F. Urol. 38, 89.

JAMESON, R. M. (1967). Br. F. clin. Pract. 21, 463.

JAMESON, R. M. (1968). Br. F. Urol. In press.

KeMP, D. R. (I966). Br. F. Surg. 53, 236.

LyN, J. M. \& NesBit, R. M. (I948). F. Urol. 89, 59I.

MOORE, T. \& Hira, N. R. (I964). Br. F. Urol. 37, 25.

NASH, (1956). Br. F. Urol. 28, 387.

Notely, R. G. (I968). Br. F. Urol. 40, 37.

O'Grady, F. \& CatTell, W. R. (I966). Br. F. Urol. 38, I 49.

Page, B. H., Miller, A. \& Paine, D. T. H. (I954). Proc. Roy. Soc. Med. 47, 8 I I.

Roberts, A. P. (1968). Communication, National Symposium on Urinary Tract Infection. Royal College of Physicians, London.

Ross, J. C. (1965). Br. F. Surg. 52, I64.

Ross, J. C. (1967). Br. F. Urol. 39, 708.

Ross, J. C., DAMANSKI, M. \& GibBon, N. O. K. (1957). Lancet, 2, I 520.

WARDENER, H. E. DE (1967). The Kidney, p. 367. London: Churchill.

WeLls, C. (1956). Br. F. Urol. 28, 333.

\title{
INTERMITTENT CATHETERISATION IN PARAPLEGIA
}

\author{
By Dr. J. J. WaLSh, M.D.
}

The history of the early treatment of the bladder in paraplegia has been discussed in a number of papers over the years and it is unnecessary to give all the details once again.

As is so often the case with a difficult problem in medicine, a number of different forms of treatment have been advocated and the popularity of each method has waxed and waned at different times and in different places. It is interesting, for example, that suprapubic cystostomy at one time very widely recommended, became outmoded following criticism by Guttmann (I947) and others. Recently an attempt has been made to revive it in a modified form, the vesicostomy recommended by Lapides and other workers (1960) but I feel that this revival will be short-lived. At present indwelling urethral catheter drainage is the most widely practised form of treatment in new lesions.

Having been faithfully married to one particular method of choiceintermittent catheterisation-for nearly 20 years I would like to present my views and experiences with this method.

Intermittent catheterisation has one particular disadvantage; it is demanding and time-consuming, particularly for medical officers, but I am convinced that this 
is justified by the results obtained. Nevertheless the time and effort involved appear to constitute the main reason why the method has not been more widely practised. Most people will agree that immediately after the onset of paraplegia or tetraplegia the bladder requires some form of artificial emptying until adequate micturition has been established, and further that the sooner this is established the better.

Our practice at Stoke Mandeville is to carry out the initial catheterisation 24 hours after the onset except occasionally where there is reason to believe the bladder is distended earlier. Incidentally, the unreliability of physical signs in diagnosing a full bladder in the very recent paraplegic can be quite astonishing. Our aim for practical purposes is to prevent distension to more than about $30 \mathrm{oz}$. in the average adult, which commonly necessitates catheterisation three times in the 24 hours. During the early days after injury in cases with fluid retention, two catheterisations per day may suffice whilst four are often required during the ensuing diuresis.

Method and Technique. The technical details of intermittent catheterisation as practised at Stoke Mandeville have been described by Guttmann (1949) and Guttmann and Frankel in 1966, and have remained virtually unchanged in recent years. There have been a few minor alterations chiefly in connection with the preparation and packing of the individual catheter set used for each operation.

One important change has been that since 1966, and as a direct result of the findings by Guttmann and Frankel, the catheterisation of female patients has also been carried out by a medical officer, in contrast with the previous practice when female catheterisations were done by trained nursing staff.

A certain amount of resentment may result from highly skilled trained nurses, feeling that they are considered incapable of carrying out a female catheterisation safely and satisfactorily, but this is of course untrue. The vital need for a very careful gentle technique in catheterising recently injured spinal cord lesions cannot be over-emphasised. At this stage, especially during the period of full vaso-motor paralysis, the delicate urethral mucosa is very liable to injury from even minor trauma. Nevertheless with training and instruction intelligent skilled nurses can become capable of carrying out the catheterisation just as efficiently as a medical officer. There are, however, other factors which make it most important that catheters are passed by the medical officer.

Firstly, and most usefully, it ensures that the medical officer is kept continuously aware of the condition of the patient's bladder and of the urine. One result of this is that, especially in cord lesions, there is a greater likelihood of re-establishing micturition at an earlier date than when a busy doctor examines the bladder only occasionally.

Another and more important result is that an experienced doctor is made aware of the development of infection within hours of its onset and usually before any clinical symptoms appear. It is illuminating how expert a medical officer can become in diagnosing urinary infection and sometimes even the organism by using tools in use a century or so ago, namely his eyes and nose.

For some years our practice was to send routine specimens of urine to bacteriology twice a week and whenever there was evidence of an infection, e.g. loss of clarity, odour, etc. The institution of chemotherapy both local and systemic was postponed until a laboratory report was available, usually after 24 hours and 
sometimes longer. It was found that quite a number of these cases with an established acute cystitis did not respond to treatment as quickly or as completely as desired. Consequently, it was decided to commence specific treatment semiblindly, pending bacteriology reports. This proved extremely beneficial and quite frequently the urine was rendered sterile before the report of the first infected specimen was received by the doctor.

At present the routine procedure is that if at any particular catheterisation the urine, previously crystal-clear, is seen to be slightly hazy or there is some other sign of infection, a specimen is immediately taken for laboratory examination. After this, and usually before the specimen is despatched to the laboratory, suitable treatment is instituted. This usually consists of local bladder washouts and systemic administration of an antibiotic or other drug chosen on the basis of the likely infecting organism. This is not as hit and miss a method as it may sound. In a well-organised ward of paraplegics with a stable medical staff there are rarely more than two or three urinary infecting organisms and usually one which is most common. Furthermore, however much we may try to excuse ourselves, the majority of urinary infections occurring in a paraplegic ward are iatrogenic and usually an example of cross-infection. In these circumstances what has been described as 'blind' chemotherapy is in fact based on a pretty accurate estimate, and this has been borne out by the findings in many hundreds of instances.

The efficiency of this method has been supported by what may be termed negative evidence. When a change of medical staff occurs and a doctor is appointed who has not had practical experience in the intermittent catheterisation of newly injured paraplegics there is invariably an increase in the percentage of infected cases on the ward. Indeed, the number of weeks required to bring the percentage of infected cases back to the usual level is a very good criterion for judging the ability and conscientiousness of the newly appointed doctor!

In our experience the régime outlined results in a minority of cases going through the period of catheterisation, usually of several weeks, without showing any evidence of urinary infection, by standard culturing and pus cells counts. The majority do at some stage (sometimes repeatedly) show pus cell counts and positive cultures indicating infection but are rendered sterile again usually in a matter of days. Few show clinical evidence of urinary infection apart from the pathological report and macroscopic appearance.

A further group, about 20 per cent., either maintains the infection present on admission or develops one during treatment and which is not eradicated before discharge. I believe that the numbers in this last group can be diminished still further, but there is likely to remain a minority of cases with chronic infection, most of them suffering from other complications, the treatment of which is still unsatisfactory.

One further point which is worth mentioning is the need to continue intermittent catheterisation, though with diminishing frequency, until adequate micturition has been established, or even longer. As an approximate rule of thumb we feel that a residual urine under $8 \mathrm{oz}$. justified only two catheterisation day and, under 4 oz., one per day Even when the residual is less than I oz. it pays dividends to catheterise once or twice a week for a further period particularly when the patient is still confined to bed. This not only guards against the recurrence of a larger residual which not infrequently develops but also prevents the collection in the bladder of sediment, including organic deposits, conducive to infection. 
Results. The results of this form of treatment are already available in the two papers I have quoted. Follow-up of these cases is at present being prepared but unfortunately it is not yet available.

The published figures show that the percentage of patients discharged with sterile urine is higher than has been described following any other method of initial treatment. Whilst appreciating that intermittent catheterisation properly carried out makes serious inroads on the working time of medical officers, I feel that from the patient's point of view the end more than justifies the means.

\title{
REFERENCES
}

Guttmann, L. (1947). Proc. Roy. Soc. Med. 40, 219.

Guttmann, L. (1949). Br. Surg. Pract. 6, 445.

GutTMAnN, L. \& Frankel, H. (I966). Int. F. Paraplegia, 4, 63.

Lapides, T., Ajemian, E. \& Lichtward, T. (i960). F. Urol. 84, 609.

\section{NEUROGENIC BLADDER: CONSERVATIVE METHODS OF TREATMENT}

\author{
By S. A. Vincent \\ Belfast City Hospital
}

Introduction. The treatment of the symptom of urinary incontinence from any cause is much influenced by the fact that, although the patient may complain only of incontinence of a varying degree, it can be found on investigation that obstruction is present as well.

This occurs even in bed-wetting children who have got frequency and urgency by day and in adult patients with exactly similar diurnal symptoms, the difference between urgency and urge-incontinence being only one of degree.

In bladders that have been deprived in whole or in part of their nerve supply the importance of the obstructive element has been emphasised by many workers, and methods of eliminating it have been described. Ross, Damanski and Gibbon (I967) have reported on a series of neurogenic bladders where division of the external sphincter has been successful in a high proportion of cases in relieving the obstructive element.

One of the conservative methods of treatment to be described depends on deliberately obstructing the flow of urine, and in using this method any obstructive effect already present must be treated with the greatest respect, whether in a neurogenic bladder or not. If it is of a degree sufficient to endanger renal function, it must form an absolute contra-indication to 'artificial mechanical obstruction' as a method of treatment.

Fortunately, the obstructive effects are not by any means proportional to the degree of incontinence. Thus, a patient may have only slight urgency and yet cystography may show increased bladder trabeculation, diverticula formation, reflux into dilated ureters, hydronephrosis and pyelonephritis. Chemical tests may show grossly impaired renal function. On the other hand, the incontinence may be very severe and investigation may fail to reveal any obstructive element, 